ACTA THERIOLOGICA

Vol. 27, 16: 213-230, 1982

\title{
Protein Polymorphisms in American Deermice (Peromyscus) and Genetic Linkage Homology
}

\author{
Wallace D. DAWSON
}

\begin{abstract}
Dawson W. D., 1982: Protein polymorphisms in American deermice (Peromyscus) and genetic linkage homology. Acta theriol., 27, 16: 213-230 [With 4 Tables \& 11 Figs.]

$F_{1}$ hybrids of laboratory stocks of deermice (Peromyscus maniculatus) and oldfield mice ( $P$. polionotus) were backcrossed to deermice. The parents and backcross progeny were typed by gel electrophoresis for hemoglobin; serum albumin, transferrin, leucine amino peptidase, and esterases; kidney esterases; and liver alcohol dehydrogenase and malic dehydrogenase. Hemoglobin, malic dehydrogenase and some esterases did not differ between species stocks. Of 15 proteins classified in backcrosses, 9 were consistently variant between or within stocks. Inheritance of each protein segregated as a mendelian co-dominant system. Two probable cases of autosomal linkage were detected: Two kidney esterases were linked by 21 centimorgans and serum transferrin and leucine amino peptidase indicated linkage by 33 centimorgans.

Linkage of esterase loci in Peromyscus is comparable to that in several other mammalian species, and probably represents phylogenetic homology. The significance of autosomal linkage conservation for evolution and development are discussed in the context of a proposed hypothesis.
\end{abstract}

[Dept. Biol., Univ. South Carolina, Columbia, S.C. 29208, U.S.A.]

\section{INTRODUCTION}

A number of lines of evidence developed recently suggest that mammals may share genetic linkage groups in common. This raises the fundamental questions whether there is a basic, underlying "genetic architecture" common to mammals, and whether this architecture is functionally related to development. If the spatial and linkage arrangement of genetic loci is functional, one would expect chromosomal segments to be protected from rearrangements by natural selection, and thus linkage groups would be evolutionarily conserved.

Unfortunately, little information is available on the detail of genome structure in mammals. At the cytological level, karyotype staining to show banding patterns permits identification of apparently homologous chromosome arms and segments between certain species. At the genetic level, linkage data are available for only a few laboratory and domestic species, and for man. The laboratory mouse, Mus musculus, is the only mammalian species in, which the chromosomes have been extensively mapped with genetic markers. 
To ascertain whether linkage conservation is a general phenomenon in mammals, information must be developed for other species. Ordinarily obtaining a genetic recombination data is a prolonged and tedious process, often involving specially bred strains. This is true whether traditional test crosses or in vitro somatic cell hybrids are analyzed. However, using closely related species, capable of producing fertile hybrids, it may be possible to generate considerable recombination data more expeditiously. This report describes a hybrid system in the American cricetid rodent genus Peromyscus, which may be useful for producing a genetic parallel model to the laboratory mouse. Some conclusions of evolutionary significance for mammalogy also are presented.

\section{STOCKS AND MATINGS}

The deermouse (Peromyscus maniculatus) is a common widespread rodent in North America. It is also highly variable, and more than 50 sub-species have been described. The prairie deermouse, P. m. bairdii, is a relatively small form, with a shorter tail, ears and feet than in most races of the species.

The oldfield mouse (Peromyscus polionotus) is a closely related species which is restricted to five southeastern states of the United States. It is smaller, paler and more fossorial than any of the deermice. In nature, the species are allopatric (Fig. 1), but when brought into the laboratory female deermice readily cross with male oldfield mice to produce small but viable, fertile hybrids.

Laboratory stocks of these two species were established more than twenty-five years ago by Lee R. Dice at the University of Michigan. One stock, P. m. bairdii from Michigan, is designated "BW", and another, $P$. polionotus from Florida, is designated "PO". Both stocks have been in captivity at least 30 generations. Sites of origin of these two stocks are indicated by circles on Figure 1 . Table 1 gives a summary of some of the stock characters.

Surveys by many investigators demonstrate that enzyme and other protein polymorphisms are very common in natural populations of Peromyscus (Rasmussen, 1970 ; Biggers \& Dawson, 1971 ; Selander et al., 1971 ; Avise et al., 1979 ; Baccus et al., 1980). Since stocks of both species are maintained in our laboratory, we recognized that the stocks would probably differ from one another in many electrophoretically distinguishable proteins. Furthermore, since the species will cross to produce fertile hybrids (Dice, 1933; Dawson, 1965), genetic studies with species hybrids permit examination of several different segregating traits 


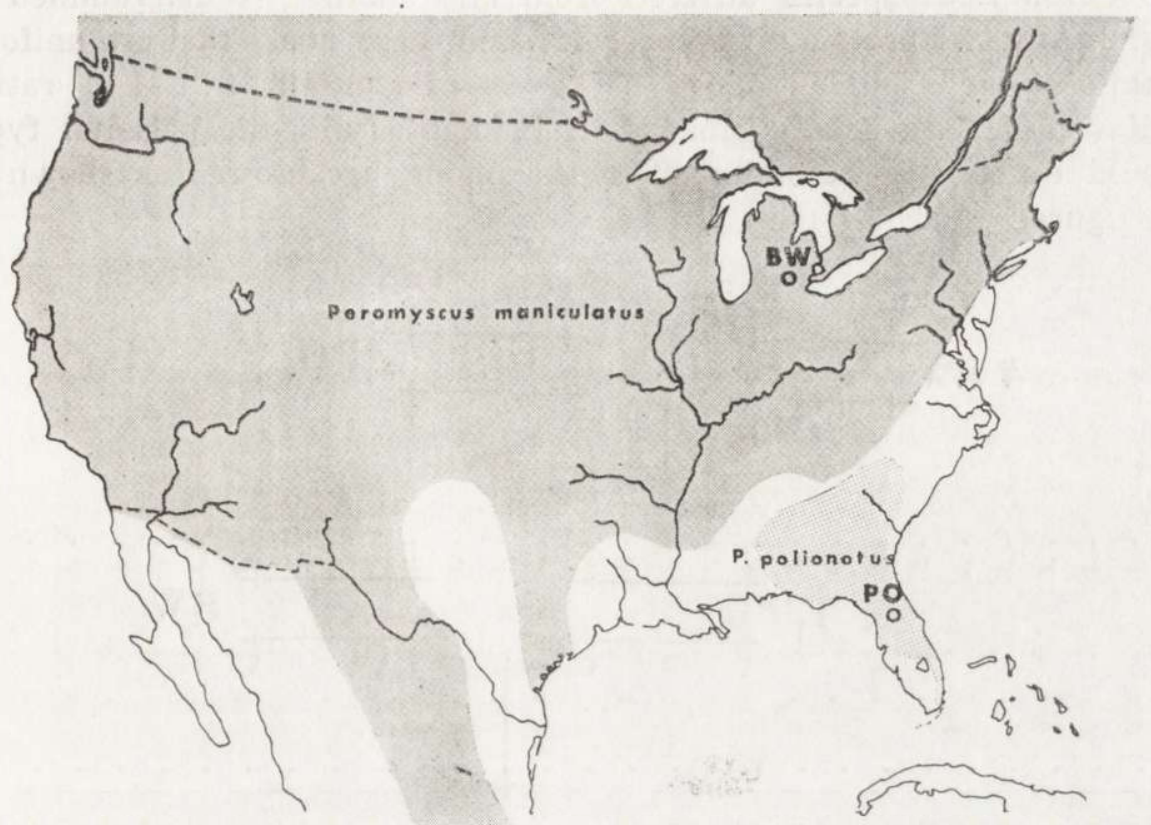

Fig. 1. Distribution of Peromyscus maniculatus and $P$. polionotus in the United States. Circles indicate sites where stock ancestors were obtained.

Table 1

Characteristics of stocks.

\begin{tabular}{|c|c|c|}
\hline Species: & $\begin{array}{l}\text { Peromyscus maniculatus } \\
\text { bairdii }\end{array}$ & $\begin{array}{l}\text { Peromyscus polionotus } \\
\text { subgriseus }\end{array}$ \\
\hline Stock: & BW ("bairdii Washtenaw") & PO ("polionotus Ocala") \\
\hline Origin: & $\begin{array}{l}\text { Washtenaw County, } \\
\text { Michigan (near Ann Arbor. } \\
\text { 1946, 1947) }\end{array}$ & $\begin{array}{l}\text { Ocala National Forest, } \\
\text { Florida, } 1951 .\end{array}$ \\
\hline $\begin{array}{l}\text { Number of original } \\
\text { ancestors }\end{array}$ & 40 maximum & 16 maximum \\
\hline Minimum ancestry & 14 (Seven matings) & 6 (Three matings) \\
\hline $\begin{array}{l}\text { Estimated average inbre- } \\
\text { eding coefficient }\end{array}$ & .30 & $F>.40$ \\
\hline Mean adult body weight & $17.96 \pm .28 \mathrm{~g}$ & $15.06 \pm .10 \mathrm{~g}$ \\
\hline Mean adult body length & $85.49 \pm 43 \mathrm{~mm}$ & $79.17 \pm 19 \mathrm{~mm}$ \\
\hline Mean litter size & $4.21 \pm .11$ & $3.65 \pm .09$ \\
\hline Coat color & $\begin{array}{l}\text { Wild-type agouti (Dark gray- } \\
\text { brown, white ventrum) }\end{array}$ & $\begin{array}{l}\text { Wild-type agouti (Sandy } \\
\text { brown, white ventrum) }\end{array}$ \\
\hline
\end{tabular}

simultaneously. $\mathrm{F}_{1}$ hybrids can be backcrossed to either species and genetic linkage tests can be conducted efficiently for proteins which show co-dominant inheritance patterns.

The mating scheme used to test for linkage between two loci by which 4-Acta Theriologica 
the Peromyscus species differed from one another is diagrammed in Fig. 2. Any two protein differences between these stocks that are uniform within stocks should produce backcross progeny in $1: 1: 1: 1$ ratios, unless there is a genetic linkage. If linkage occurs, the parental types should exceed the recombinant types among backcrosses as shown in the figure.

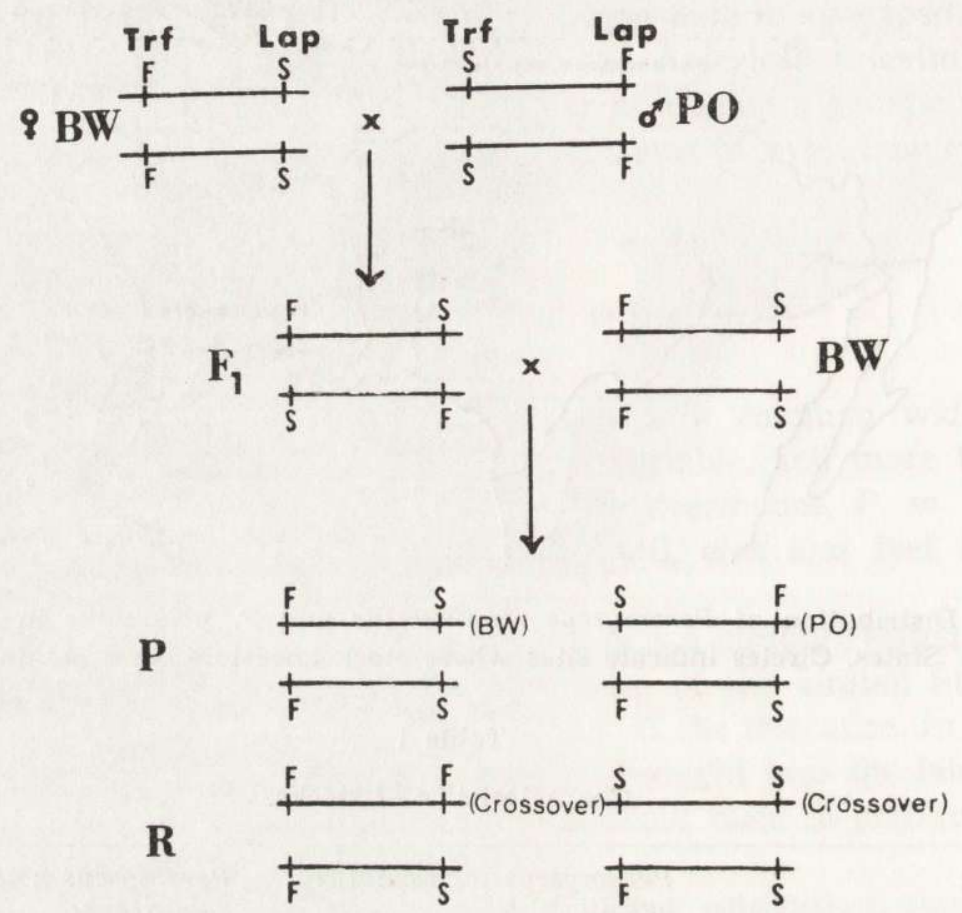

Fig. 2. Mating scheme employed to detect linkage, using, as an example, linkage of transferrin (Trf) and leucine amino peptidase (Lap) loci.

Six productive backcrosses were established as pair matings of female $\mathrm{BW}$ to male $\mathrm{F}_{1}$ in individual cages. Since the BW and PO laboratory stocks differed for a variety of serum protein electrophoretic traits, iinkage tests for these characters were tested simultaneously from a single group of 78 backcross progeny. A sub-sample of 33 were tested for kidney esterases and 19 of these for liver alcohol dehydrogenase. Seminal vesicle protein was surveyed in both stocks.

\section{SAMPLING AND ELECTROPHORETIC METHODS}

Whole blood samples were collected by orbital puncture in $0.1 \mathrm{ml}$ capillets and centrifuged to separate the serum which was then electrophoresed. Albumin 
and transferrin were typed using either polyacrylamide gel or starch gel electrophoresis or both. Serum esterases and leucine aminopeptidase were typed using starch gel electrophoresis. Each animal was serum-typed at least twice.

For acrylamide gel electrophoresis 5-6\% gels were prepared using the E-C vertical cell apparatus. Either eight or sixteen samples were run on a single gel in a continuous $0.18 \mathrm{M}$ tris-borate buffer, $\mathrm{pH}$ 8.4. The sample was run at 300 volts for $2^{1 / 2}$ hours. Gels were stained with amino black in acetic acidmethanol aqueous solution. After de-staining, the samples were scored for albumin and transferrin type.

For starch gel electrophoresis $12 \%$ electrostarch gels were prepared for horizontal electrophoresis, using a cell with a 16 sample capacity. Serum samples were run for 5 or 6 hours at $3^{\circ}-4^{\circ} \mathrm{C}$, using $0.2 \mathrm{M}$ lithium borate buffer, $\mathrm{pH} 8.3$, at 150 to 300 volts. Following electrophoresis each gel was sliced horizontally into three sheets and stained for (1) albumin and transferrin, (2) esterases and (3) leucine amino peptidase. Amido black was used to stain for albumin and transferrin. For esterase typing, gels were incubated for $10 \mathrm{~min}$ at $37^{\circ} \mathrm{C}$ with $\alpha$-napthyl acetate and $\alpha$-napthyl butyrate substrate in a $\mathrm{pH} 7.4$ phosphate buffer and $\mathrm{RR}$ fast blue stain. The stain reaction was stopped and gels preserved in an acetic acidglycerol wash. Esterase activity is identified as brown bands on the gel.

To detect leucine amino peptidase, gel slices were incubated overnight at $37^{\circ} \mathrm{C}$ with L-leucyl $\beta$ napthylamide in $0.2 \mathrm{M}$ tris maleate buffer, $\mathrm{pH} 3.3$, with the stain reagent, black $\mathrm{K}$ salt and $0.2 \mathrm{~N} \mathrm{NaOH}$.

For identification of kidney esterases and liver alcohol dehydrogenases, fresh or recently frozen tissues were homogenized in a phosphate buffer, the suspension centrifuged, and the supernatant electrophoresed on starch gel. To identify esterase, the electrophoretic conditions and stain reactions were the same as those used for serum esterases.

Liver alcohol dehydrogenase was typed following the procedure of Felder (1975). Samples were electrophoresed for $5 \mathrm{hrs}$ at $3^{\circ}-4^{\circ} \mathrm{C}$ at 160 volts in a $.2 \mathrm{M}$ tris glycine buffer, $\mathrm{pH}$ 8.3. The stain reaction utilized a nicotinamide adenine dinucleotide and ethanol substrate incubated at $37^{\circ} \mathrm{C}$ in a nitro-blue tetrazoleum reagent with a tris $\mathrm{HCl}$ buffer, $\mathrm{pH}$ 8.0. Cathodally migrating alcohol dehydrogenase bands were scored.

\section{RESULTS}

The two Peromyscus stocks were surveyed for 15 identifiable proteins (Table 2). They differed for nine of these, each involving a separate genetic locus. Not every animal used could be classified unambiguously for each protein. Only where duplicate samples were scored identifically by two or more independent observers, were the data accepted for genetic analysis. For example, some animals were classified for albumin, but serum esterase classification was doubtful; therefore, the number of animals available for linkage tests was somewhat fewer than the total number typed.

Serum albumin. The BW stock had a single albumin band (electro- 
Table 2

Electrophoretic phenotypes of Peromyscus stocks.

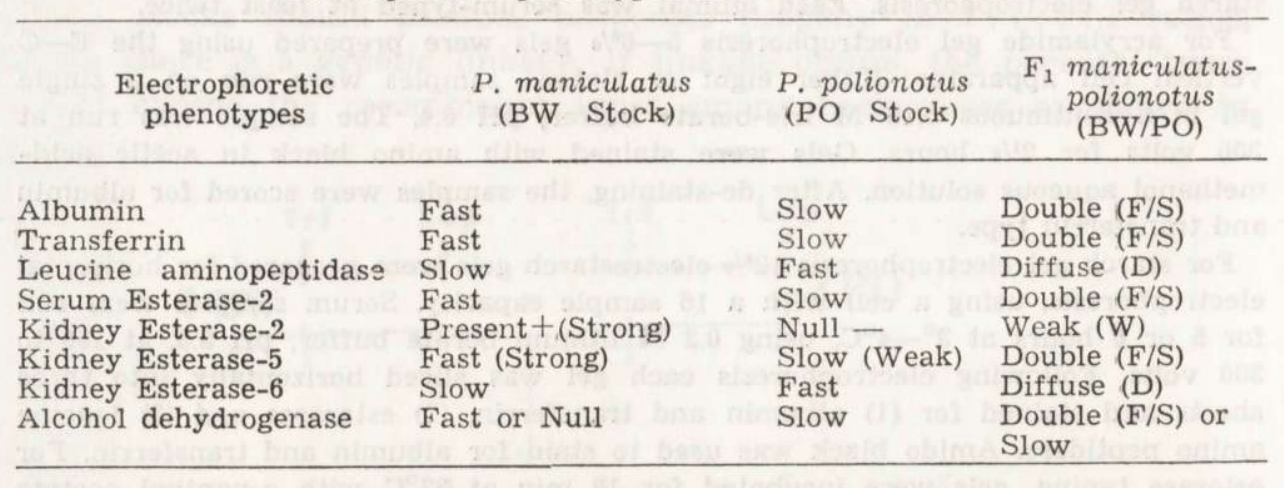

Stocks are electrophoretically indistinguishable for hemoglobin and malate dehydrogenase. The BW stock shares a seminal vesicle protein (SVP) in common with $\mathrm{PO}$, but some BW individuals have a second SVP phenotype.

morph) which was faster than the single band in PO. The $\mathrm{F}_{1}$ hybrid showed a double band phenotype, typical of co-dominance (Fig. 3). Albumin inheritance in Peromyscus was previously studied by Brown \& Welser (1968).

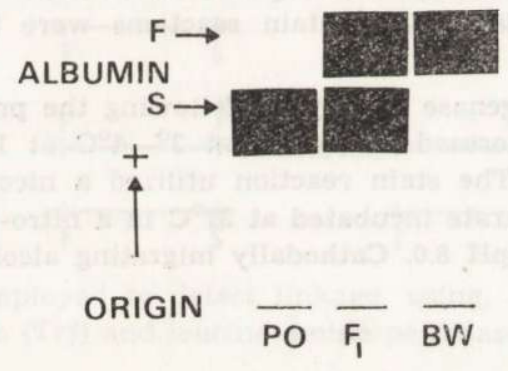

Fig. 3. Serum albumin electrophoretic differences in Peromyscus on acrylamide gel: $\mathrm{BW}$, fast; $\mathrm{PO}$, slow; $\mathrm{F}_{1}$, double bands.

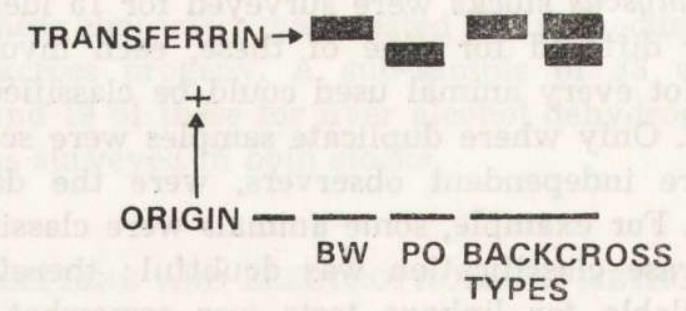

Fig. 4. Serum transferrin electrophoretic differences in Peromyscus on starch gel: $\mathrm{BW}$, fast; PO, slow; backcrosses segregating either fast or double bands. 
Serum transferrin. The BW stock had a faster transferrin electrophoretic band due to the $\operatorname{Trf}^{b}$ allele in homozygous condition. PO was slower due to homozygous $\operatorname{Tr} f^{c}$. The heterozygous $\mathrm{F}_{1}$ hybrid, $\operatorname{Tr} f^{b} / \operatorname{Tr} f^{c}$, had a double band pattern (Fig. 4). The formal genetics of this locus is well established (Griswold \& Dawson, 1971).

Serum leucine aminopeptidase. Serum leucine aminopeptidase migrated in the post-albumin region. In Peromyscus three bands of approximately equal activity were apparent in both stocks. The first and third bands were not variant, but the middle band in the $P$. maniculatus stock migrated more slowly than in PO. The $F_{1}$ phenotype could not be resolved into a clearly defined double band by our methods, but rather appeared as a diffuse band. However, since the BW band was slower than the one in PO, no difficulty in classifying backcross progeny was experienced, the diffuse band having a faster front than the BW band segregant (Fig. 5),

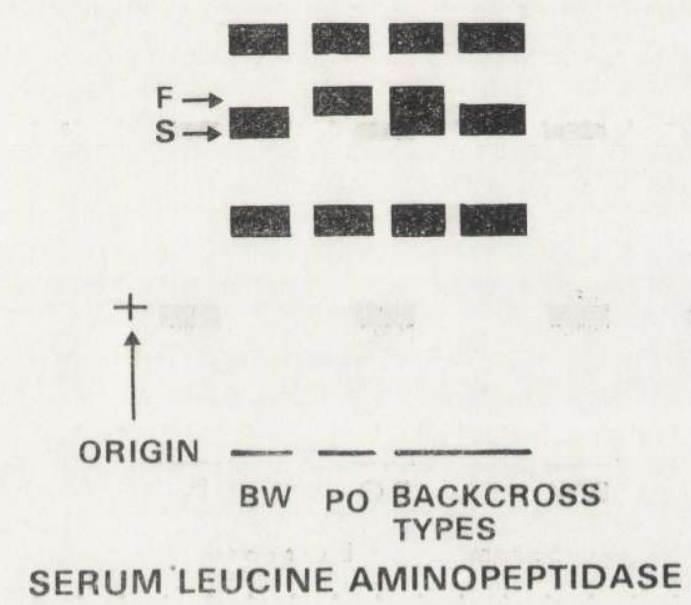

Fig. 5. Serum leucine aminopeptidase patterns in Peromyscus on starch gel: The middle band varies: BW, slow; PO, fast; backrosses segregating either slow or diffuse.

Serum esterases. Serum esterases in Peromyscus are complex and vary greatly depending upon electrophoretic conditions, substrates and other factors. Figure 6 is a diagramatic scheme of the major esterase differences in the BW and PO stocks. There appeared to be five major esterase active regions, which we designated esterase 1 through 5 . The BW and PO stocks differed for both the esterase 1 and 2 regions. The esterase- 1 band was completely absent in PO. The $F_{1}$ exhibited the band, but less intensely than in BW. However, while the intensity difference in the homozygous and heterozygous mice was apparent on acrylamide gels, 
our backcrosses were scored on starch gel where they cannot consistently be distinguished. Therefore, we did not conduct genetic analysis or linkage tests with serum esterase-1.

Serum esterase-2, which occurs in the albumin region, produced a faster band in $\mathrm{BW}$ and a slower band in PO. The $\mathrm{F}_{1}$ interspecific hybrids had a close, but distinct, double band pattern, indicating codominance.

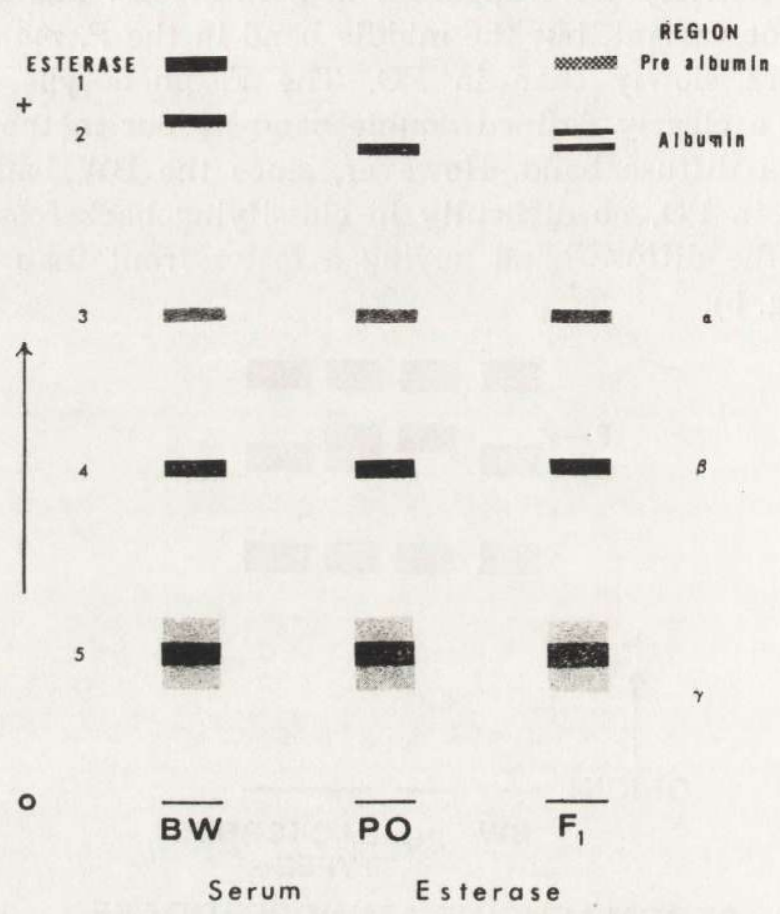

Fig. 6. Diagram of serum esterase patterns in Peromyscus. See text for explanation.

Kidney esterases. Six major zones of anodally migrating kidney esterases were recognized (Fig. 7). Some zones contained multiple bands. Three zones, tentatively designated kidney esterase-2, 5 and 6 , consistently differed between the Peromyscus species stocks. Esterase-2 stained as a slow, faint band in PO, but as a faster, denser band in BW. The $F_{1}$ had a weak, diffuse band, with distinctly less activity than the BW. Backcross progeny were phenotyped as intense or weak.

Kidney esterase- 5 occurred in a zone among several bands of intermediate electrophoretic mobility. PO had slower, less intensely staining bands than $\mathrm{BW}$. The $\mathrm{F}_{1}$ hybrid had weak multiple staining bands. Backcross progeny were scored as fast-strong or mutiple-weak. 
Esterase-6 occurred as a faintly staining band of low mobility, migrating well behind the other anodal esterases. Esterase- 6 migrated more slowly in $\mathrm{BW}$ than in $\mathrm{PO}$, with the $\mathrm{F}_{1}$ presenting a diffuse phenotype. Backcross offspring were scored as slow single band or diffuse.

Within the PO stock, additional variation exists in zone 3. In BW, zones 4 and 5 vary within the stock.

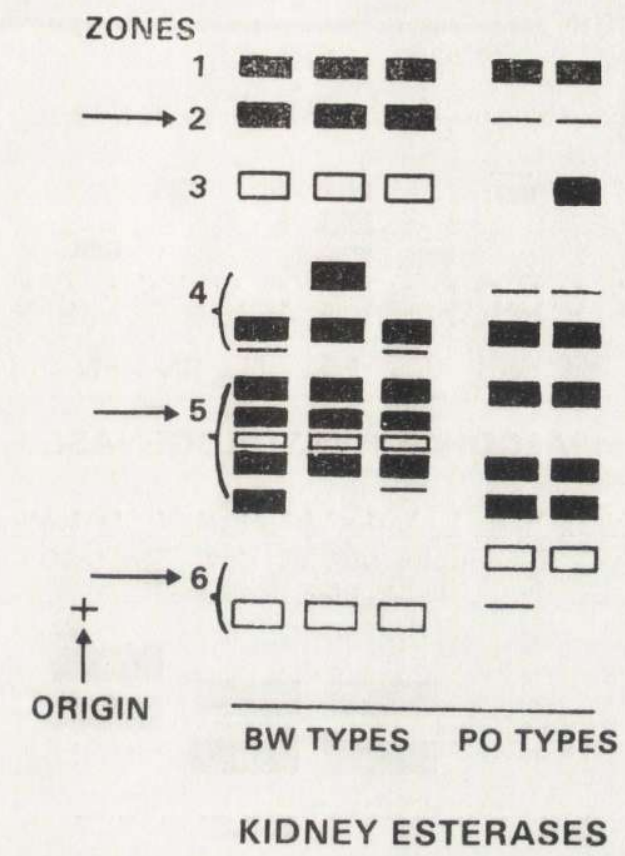

Fig. 7. Peromyscus kidney esterases on starch gel. Species differences occur in bands indicated by arrows, Es-2, 5, and 6 .

Liver alcohol dehydrogenase. Liver alcohol dehydrogenase (ADH) in BW may type either as a fast single band or absent (null). The PO stock is monomorphic for a slow ADH band. The $F_{1}$ interspecific hybrid, then, may be either double banded (fast-slow) or slow single banded (slownull) (Burnett \& Felder, 1978). Backcrosses to BW were expected to produce mice which could be double banded, slow single, fast single or null. Any animals with a slow $\mathrm{ADH}$ band would have derived the trait from PO. All of the expected types were found among the backcross offspring. The ADH phenotypes are illustrated in Figure 8.

Seminal vesicle protein. Variation from seminal vesicle protein (SVP) occurred in Peromyscus maniculatus which were typed from the BW and other stocks (Fig. 9). Slow, fast and double band phenotypes appeared. The PO stock was uniform for a seminal vesicle protein, which could 
not be distinguished from the SVP band in the BW stock. Therefore, it was not a useful linkage marker in these studies.

Genetic segregation. Each of the protein traits analyzed here except $\mathrm{ADH}$ showed consistent $1: 1$ segregation of alleles among progeny of interspecific $F$. maniculatus-polionotus $\mathrm{F}_{1}$ hybrids backcrossed to the $\mathrm{BW}$ stock of P. maniculatus (Table 3). Each was consistent with a di-allelic

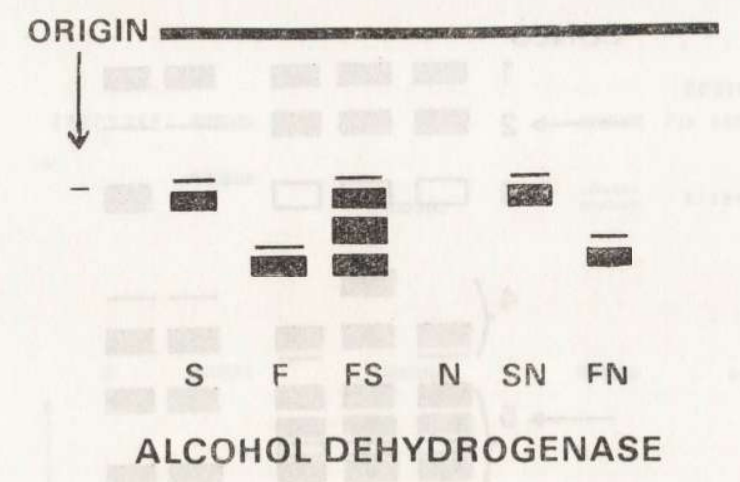

Fig. 8. Alcohol dehydrogenase variation in Peromyscus stocks on starch gel: BW, fast or null; $P O$, slow; $F_{1}$, double, fast or slow. See text for explanation. (From Felder, 1975).

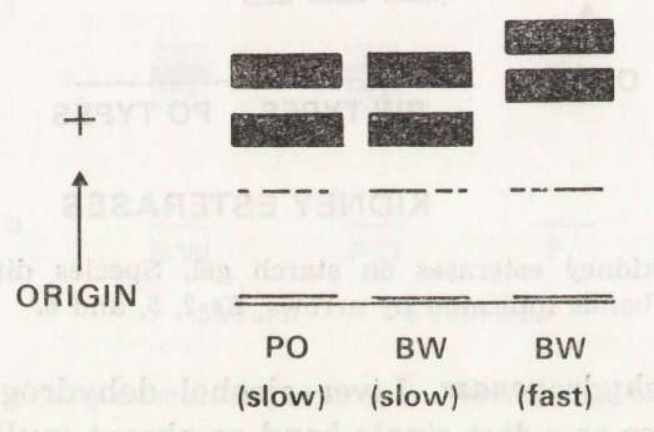

SEMINAL VESICLE PROTEIN

Fig. 9. Seminal vesicle protein phenotypes. Variation occurs in Peromyscus maniculatus. PO is uniform.

model of inheritance. The variant for liver ADH earlier had been shown by Felder (1975) to be due to the three allele system, with alleles $A d h^{F}$ and $A d h^{\mathrm{s}}$ co-dominant, and the null allele, $A d h^{\circ}$, recessive.

Genetic linkage. Using backcross data, genetic linkage was tested for each pair of characters employing analysis of chi-square. The criteria for positive evidence of linkage were (1) non-significant deviations from 


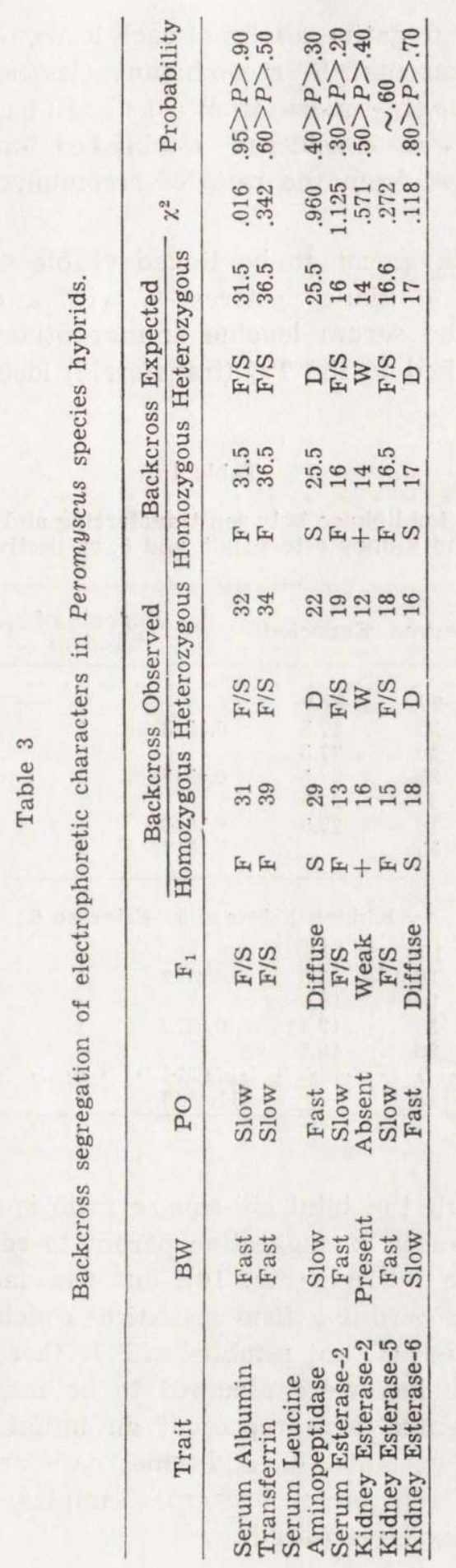


1: 1 ratios for the segregating alleles at each locus, $(2)$ significant $(\mathrm{P}<.05)$ deviations of the parental to recombinant classes, and (3) significant deviation of the total chi-square, from a $1: 1: 1: 1$ ratio. If all conditions obtained, linkage was considered established and the recombinant fraction, $\Theta$, estimated from the ratio of recombinant types (crossovers) to the total.

Two pairs of loci appear to be linked (Table 4). Kidney esterase-5 was clearly linked to kidney esterase-6, with a recombinant fraction estimated at .21. The serum leucine aminopeptidase locus, Lap, apparently is loosely linked to the Trf (transferrin) locus, with an estimated

\section{Table 4}

Analysis of Chi-square for linkage between transferring and leucine aminopeptidase; and kidney esterases 5 and 6 , respectively.

\begin{tabular}{|c|c|c|c|c|c|c|}
\hline Test & Observed & Expected & $\chi^{2}$ & $\begin{array}{l}\text { Degrees of } \\
\text { freedom }\end{array}$ & Probability & $\begin{array}{c}\text { Recombinant } \\
\text { fraction }\end{array}$ \\
\hline Trf (Fast) & 29 & 27.5 & \multirow[b]{2}{*}{0.1613} & \multirow{3}{*}{1} & \multirow[b]{2}{*}{$.7-.6$} & \multirow[b]{7}{*}{0.33} \\
\hline Trf (Slow) & 26 & 27.5 & & & & \\
\hline Lap (Slow) & 30 & 27.5 & & & \multirow{3}{*}{$\sim .5$} & \\
\hline Lap (Fast) & 25 & 27.5 & \multirow{2}{*}{0.4545} & 1 & & \\
\hline Parental & 37 & 27.5 & & & & \\
\hline Recombinant & 18 & 27.5 & 6.5636 & 1 & $.05-.01$ & \\
\hline Total & 55 & & 7.1817 & 3 & $.10-.05$ & \\
\hline \multicolumn{7}{|c|}{ Kidney Esterase 5 -Esterase 6} \\
\hline Ee-5 (Fast) & 15 & 16.5 & & & & \\
\hline Es-5 (Slow) & 18 & 16.5 & 0.2727 & 1 & $\sim .6$ & \\
\hline Ee-6 (Fast) & 18 & 16.5 & & & & \\
\hline Es-6 (Slow) & 15 & 16.5 & 0.2727 & 1 & $\sim .6$ & \\
\hline Parental & 26 & 16.5 & & & & \\
\hline Recombinant & 7 & 16.5 & 10.9394 & 1 & $<.001$ & \\
\hline Total: & 33 & & 11.4848 & 3 & $<.001$ & 0.21 \\
\hline
\end{tabular}

$33 \Theta$ value, although the total chi-square ratio is of borderline significance. Several instances of suggestive parent to recombinant data indicated possible loose linkage (Fig. 10), but the data samples were not sufficiently large to permit a firm statistical conclusion. In these cases, linkage was indicated as "not established." If there was no evidence of linkage, the genetic loci were assumed to be inherited independently.

The results presented here represent an initial survey of a limited number of protein variants. As additional data are collected for these and other proteins from larger backcross samples, some modification of these conclusions may be required. 


\section{DISCUSSION}

Although, except for Mus musculus and Homo sapiens, knowledge of genetic linkage in mammals is extremely scant (Robinson, $1972 ; \mathrm{McKu}$ sick, 1980), homologous linkage groups have been demonstrated for several species. Three well documented examples are summarized in Figure 11.

The albino locus, $c$, is linked to pink-eye dilution, $p$, in laboratory mouse (Mus musculus), rat (Rattus norvegicus), and deermouse (Pero-

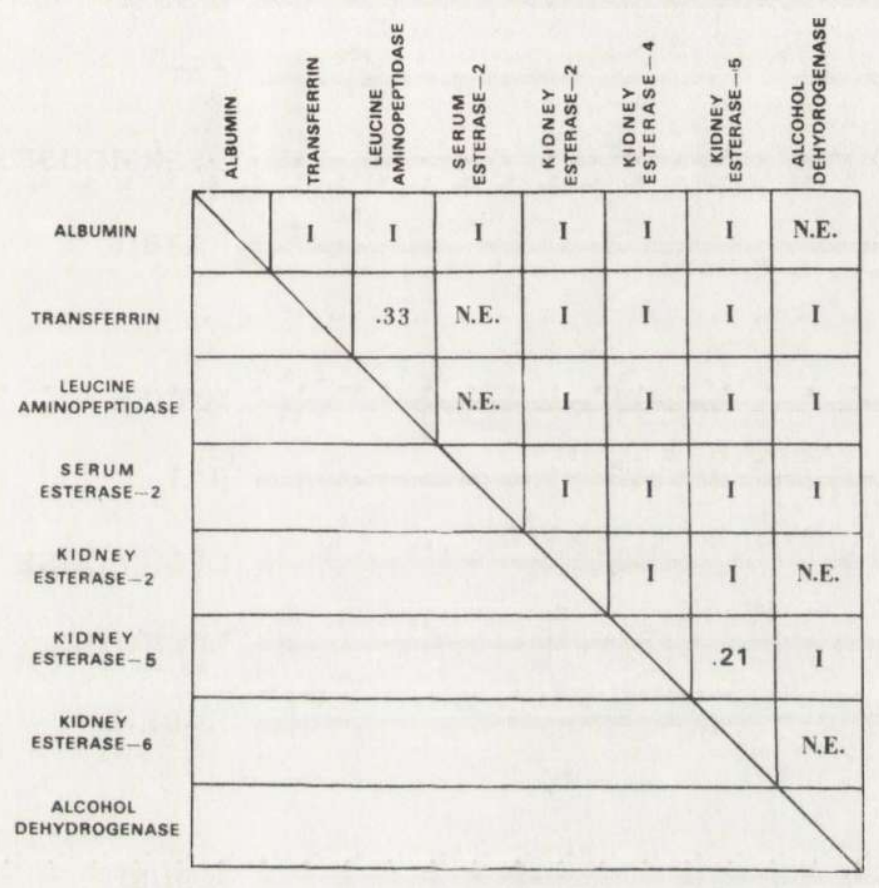

Fig. 10. Diagram of linkage tests performed. $I=$ independent assortment; N.E.= linkage possible, but not established. Values are recombinant fractions, where linkage was probable.

myscus maniculatus) (Robinson, 1972). In each species the map distance is on the order of 15 centimorgans (cM) (=15\% crossing over). The structural gene for the hemoglobin $\beta$ chain, $\mathrm{Hbb}$. is linked to the $c$ locus in mouse (Popp, 1962; Hutton \& Roderick, 1970), rat (Moutier et al., 1973a) and rabbit by about $6 \mathrm{cM}$. The linkage order in both rat and mouse is $p-c-H b b$. Thus the pink-eye dilution/albino/hemoglobin group is established, These loci, in Linkage Group I (Chromosome 7) of the rat 
and Group I of the deermouse, have remained intact since their common origin in the Pliocene or before. Snyder (1980) has evidence that the glucose phosphate isomerase, Gpi-1, locus in Peromyscus is also in this group as it is in Mus musculus.

Linkage Group XVIII (Chromosome 8) of the mouse contains at least three non-specific esterase loci, Es-1, Es-2 and Es-5, within a $12 \mathrm{cM}$ segment (Popp, 1967; Ruddle et al., 1969). Linkage Group V of the

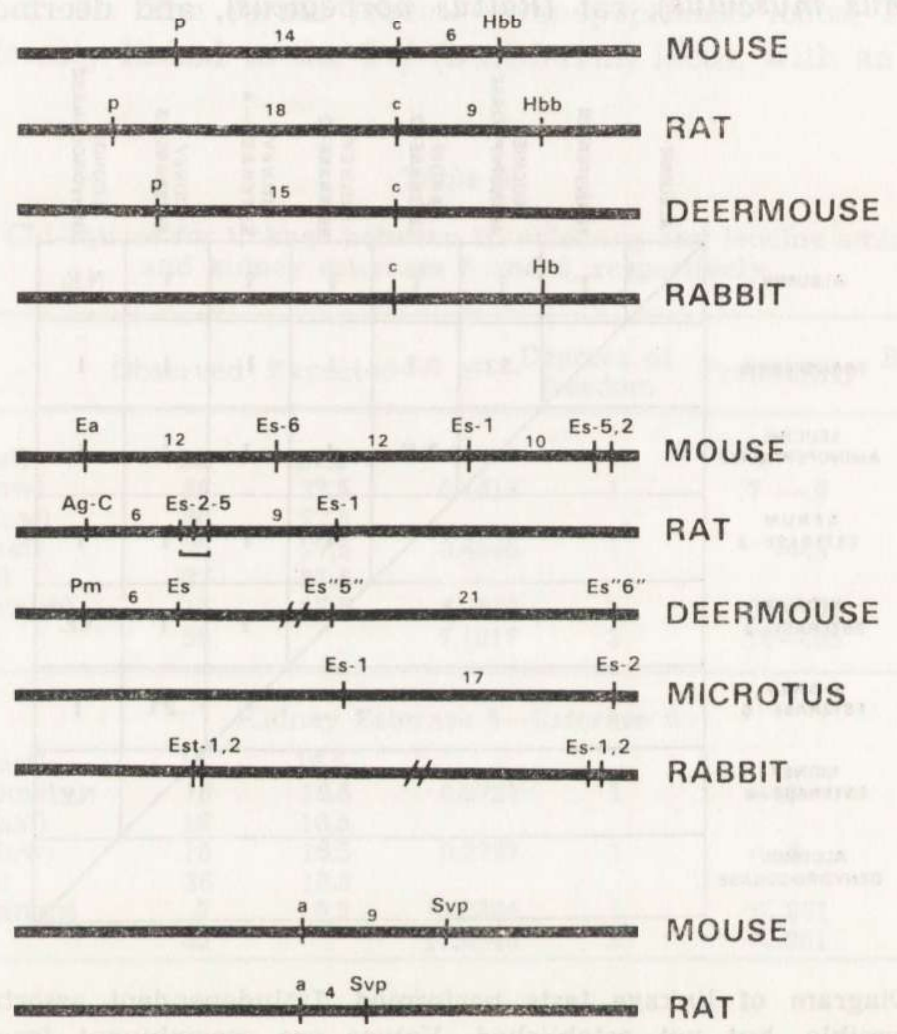

Fig. 11. Linkage homology shown in three mammalian autosomal groups. Double slashed lines, //, indicate that linked groups in the same organism have not been tested to each other.

laboratory rat also contains several esterase loci within a $9 \mathrm{cM}$ segment (Womack, 1981 ; Serov, 1973 ; Moutier et al., 1973b ; Womack \& Sharp, 1976). A major erythrocytic antigen locus, $E a-1$ in the mouse and $A g-C$ in rat, is linked with these esterase genes in both cases (Foster et al., 1968; Gasser et al., 1973). Linked esterase loci are also found in Microtus 
ochrogaster (Semeonoff, 1972) and rabbit, Oryctolagus cuniculus (Schiff \& Stormont, 1970 ; van Zutphen, 1974). A major erythrocytic antigen locus, $P m$, is linked to erythrocytic esterase, Es, in Peromyscus maniculatus (Randerson, 1973). Thus, the multiple esterase-erythrocytic antigen group represents a second case of conserved linkage.

The agouti $(\alpha)$ - seminal vesicle protein $(S v p)$ linkage constitutes a third example. The agouti coat color locus is located $9 \mathrm{cM}$ from $S v p$ in Linkage Group V (Chromosome 2) of the mouse, and $4 \mathrm{cM}$ in Group IV of the rat (Platz \& Wolfe, 1969; Moutier et al., 1973a; Gasser, 1972).

This study demonstrates the probable linkage of leucine aminopeptidase, Lap, and transferrin, Trf, by about $33 \mathrm{cM}$. The Lap and Trf loci in Mus are linked by approximately $30 \mathrm{cM}$ (Womack et al., 1975) representing another conserved autosomal linkage of extensive length. Fourteen human linkages of biochemical markers, indentified by somatic cell methods, correspond to Mus linkage groups, and four human chromosome arms are syntenic with ones in sheep (Ovis), cattle (Bos), cat (Felis) and several higher primates (McKusick, 1980). Comparison between Giemsa banding patterns of chromosomes of several Peromyscus species reveals close similarity (Mascarello et al., 1974 ; Greenbaum, et al., 1978).

The present study demonstrates linkage of loci for nonspecific kidney esterases in deermice, a parallel of mouse, rat, rabbit and Microtus (Fig. 11). Peromyscus leucine aminopeptidase and transferrin also appear to be linked by approximately the same distance as in the mouse. These observations lend further support to the concept of autosomal conservation.

Laboratory stocks of two closely related species of Peromyscus were dissimilar for $60 \%$ of the 15 identifiable proteins. This suggests that even very closely related mammalian species probably differ in the primary sequence of most of their proteins.

The use of fertile species hybrids backcrossed to parent types provides a means of testing for genetic linkages in other mammalian taxa, and for testing further the concept of conserved linkage. Details of linkage homologies, when known and compared, could assist in resolving questions in systematic and taxonomy. They could also be used in concert with karyotypes to locate gene sites on a specific chromosomes.

Acknowledgements: The generous advice and assistance of my colleague, Michael R. Felder, is gratefully acnowledged. Dr. Felder kindly conducted the alcohol dehydrogenase electrophoresis. Thanks are due Sharon Maier for technical assistance. The author is grateful for financial support from the George H. Bunch Chair endowment.

This report is based on a paper "Genetic Polymorphisms and the Relationship between Peromyscus polionotus and P. maniculatus" presented at the First International Theriological Congress, Moscow, USSR, June 5-12, 1974. In recognition of his significant role in organization of the First Congress, I respectfully dedicate this article to Professor N. N. Vorontsov. 


\section{REFERENCES}

1. Avise J. C., Smith M. H. \& Selander R. K., 1979: Biochemical polymorphism and systematics in the genus Peromyscus VIII. Geographic differentiation in members of the truei and maniculatus species groups. J. Mammal., 60: 177-192.

2. Baccus R., Joule J. \& Kimberling W. J., 1980: Linkage and selection analysis of biochemical variants in Peromyscus maniculatus. J. Mammal., 61: 423-435.

3. Biggers C. J. \& Dawson W. D., 1971: Serum protein polymorphisms in Peromyscus polionotus of South Carolina. J. Mammal., 52: 376-385.

4. Brown J. H. \& Welser C. F., 1968: Serum albumin polymorphisms in natural and laboratory populations of Peromyscus. J. Mammal., 49: 420-426.

5. Burnett K. G. \& Felder M. R., 1978: Genetic regulation of liver alcohol dehydrogenase in Peromyscus. Biochem. Genet., 16: 443-454.

6. Dawson W. D., 1965: Fertility and size inheritance in a Peromyscus species cross. Evolution, 19: $44-45$.

7. Dice L. R., 1933: Fertility relationships between some of the species and subspecies of mice of the genus Peromyscus. J. Mammal., 14: 298-305.

8. Egozcue J., Aragones J., Caballin M. R. \& Goday C., 1973a: Banding patterns of the chromosomes of man and gorilla. Ann. Genet., 16: 207-210.

9. Egozcue J., Caballin M. R. \& Goday C., 1973b: Banding patterns of the chromosomes of man and the chimpanzee. Humangenetik, 18: 77-80.

10. Felder M. R., 1975: Tissue distribution and genetics of alcohol dehydrogenase isozymes in Peromyscus. [In: "Isozymes", v. 3. Developmental Biology, Ed. C. L. Markert]. Academic Press, New York.

11. Felder M. R., 1980: Biochemical and developmental genetics of isozymes in the mouse, Mus musculus. [In: "Isozymes: Current Topics in Biological and Medical Research"]. 4: 1-68.

12. Foster M., Petras M. L. \& Gasser D. L., 1968: The Ea-1 blood group locus of the house mouse: Inheritance, linkage, polymorphism and control of antibody synthesis. Proc. XII Internat. Cong. Genet., 1: 245.

13. Gasser D. L., 1972: Seminal vesicle protein in rats: A gene in the fourth linkage group determining electrophoretic variants. Biochem. Genet., 6: 61-63.

14. Gasser D. L., Silvers W. K., Reynolds H. M., Black G. \& Palm J., 1973: Serum esterase in rats: Two new alleles at $E s-2$, a new esterase regulated by hormonal factors, and linkage of these loci to the $\mathrm{Ag}-\mathrm{C}$ blood group locus. Biochem. Genet., 10: 207-217.

15. Greenbaum I. F., Baker R. J. \& Ramsey P. R., 1978: Chromosomal evolution and the mode of speciation in three species of Peromyscus. Evolution, 32: $646-654$.

16. Griswold K. E. \& Dawson W. D., 1971: Transferrin and haptoglobin inheritance in Peromyscus. J. Hered., 62: 339-341.

17. Hutton J. J. \& Roderick T. H., 1970: Linkage analysis using biochemical variants in mice. III. Linkage relationships of eleven biochemical markers. Biochem. Genet., 4: 339-350.

18. Hsu T. C. \& Benirschke K., 1967: An Atlas of Mammalian Chromosomes. Spring-Verlag: 1-212. New York.

19. McKusick R. A., 1980: The anatomy of the human genome. J. Hered., 71:370-391.

20. Moutier R., Toyama K. \& Charrier M. F., 1973a: Biochemical polymorphism in the rat, Rattus norvegicus: Genetic study of four markers. Biochem. Genet., 8: $321-328$. 
21. Moutier R., Toyama K. \& Charrier M. F., 1973b: Evidence for linkage between four esterase loci in the rat (Rattus norvegicus). Biochem. Genet., 9: 109-115.

22. Pathak S. \& Stock A. D., 1974: The X chromosomes of mammals: Karyological homology as revealed by banding techniques. Genetics, 78: 703-714.

23. Platz R. D. \& Wolfe H. G., 1969: Mouse seminal vesicle proteins: The inheritance of electrophoretic variants. J. Hered., 60: 187-192.

24. Popp R. A., 1962: Studies of the mouse hemoglobin loci. II. Position of the hemoglobin locus with respect to albinism and shaker-1 loci. J. Hered., 43: $73-75$.

25. Popp R. A., 1967: Linkage of $E s-1$ and $E s-2$ in the mouse. J. Hered. 58: 186-188.

26. Randerson S., 1973: Linkage of two loci in the deermouse. J. Hered., 64: $371-372$.

27. Rasmussen D. I., 1970: Biochemical polymorphism and genetic structure in populations of Peromyscus. Symp. zool. Soc. London, 26: 335-349.

28. Robinson R., 1972: Gene Mapping in Laboratory Mammals. Part. B. Plenum Press, London.

29. Ruddle F. H., Shows T. B. \& Roderick T. H., 1969: Esterase genetics in Mus musculus: Expression, linkage and polymorphism of locus Es-2. Genetics, 62: 393-399.

30. Schiff R. \& Stormont C., 1970: The biochemical genetics of rabbit erythrocyte esterases: Two new esterase loci. Biochem. Genet., 4: 11-23.

31. Selander R. K., Smith M. H., Yang S. Y., Johnson W. E. \& Gentry J. B., 1971: Biochemical polymorphism and systematics in the genus Peromyscus. I. Variation in the old-field mouse (Peromyscus polionotus). Univ. Texas Studies in Genetics, 6: 49-90.

32. Semeonoff R., 1972: Esterase polymorphism in Microtus ochrogaster: Interaction and linkage. Biochem. Genet., 6: 125-138.

33. Serov O. L., 1973: Genetic control of two esterases of rat plasma (Rattus norvegicus). Biochem. Genet., 9: 117-130.

34. Snyder L. R. G., 1980: Evolutionary conservation of linkage groups: Additional evidence from murid and cricetid rodents. Biochem. Genet., 18: 209-220.

35. van Zutphen L. F. M., 1974: Serum esterase genetics in rabbits. II. Genetic analysis of the pre-albumin esterase system, including atropinesterase and cocainesterase polymorphism. Biochem. Genet. 12: 327-343.

36. Womack J. E., 1981: The linkage map of the rat. Behav. Genet., 11: 437-444.

37. Womack J. E., Lynes M. A. \& Taylor B. A., 1975: Genetic variation of an intestinal leucine arylaminopeptidase $(L a p-1)$ in the mouse and its location on chromosome 9. Biochem. Genet., 13: 511-518.

38. Womack J. E. \& Sharp M., 1976: Comparative autosomal linkage in mammals: Genetics of esterases in Mus musculus and Rattus norvegicus. Genetics, 82: $665-675$. 
Wallace D. DAWSON

\section{POLIMORFIZM BIAŁEK U PEROMYSCUS I HOMOLOGIA SPRZEZŻEŃ GENETYCZNYCH}

\section{Streszczenie}

Hybrydy pierwszego pokolenia $F_{1}$ Peromyscus maniculatus i $P$. polionotus krzyżowano wstecznie w kierunku $P$. maniculatus (Tabela 1, Ryc. 1). Badano metodą elektroforezy żelowej, u rodziców i potomstwa, hemoglobinę, albuminy w surowicy, transferynę, leucyno-amino-peptydazę, i esterazy; esterazę nerek i dehydrogenazę alkoholową oraz dehydrogenazę kwasu jabłkowego $\mathrm{z}$ wątroby (Tabela 2, 3, Ryc. 2-9). Hemoglobina, dehydrogenaza kwasu jabłkowego i niektóre esterazy nie różniły się u badanych pokoleń. Z 15 białek wyróżnionych u krzyżówek wstecznych, 9 było różnych wewnątrz lub między grupami (Tabela 4). Każde wydzielone białko dziedziczyło się w ko-dominującym systemie mendlowskim.

Wykryto dwa prawdopodobne przypadki autosomalnego sprzężenia: dwie esterazy nerek sprzężone były o 21 centimorganów, a transferyny surowicy i leucyno-amino-peptydazy wykazują sprzężenie 33 centymorgany.

Sprzężenie loci esterazy u Peromyscus jest porównywalne do takich u innych gatunków ssaków i prawdopodobnie reprezentuje filogenetyczną homologię (Ryc. 10, 11). Dyskutuje się istotność sprzężeń dla ewolucji i rozwoju i przedkłada się objaśniającą hipotezę. 